\title{
DOUBLE CHECKING THE DOCTOR'S CREDENTIALS: THE NEW MEDICAL EXPERT QUALIFICATION STATUTE OF MCARE
}

\author{
Justin H. Werner
}

\section{INTRODUCTION}

The problem of rapidly escalating premiums paid by doctors for medical malpractice insurance has plagued Pennsylvania in the last decade. ${ }^{1}$ These rates have uprooted Pennsylvania doctors from their local practices and hospitals in favor of out-of-state locations with lower rates. ${ }^{2}$ Furthermore, some Pennsylvania doctors and hospitals specializing in high-risk procedures have refused to perform high-risk surgeries or have limited their practice to more routine procedures. ${ }^{3}$

In an effort to improve the medical malpractice landscape, the Pennsylvania legislature, recognizing that maintaining high quality health care requires "medical professional liability insurance . . . to be obtainable at an affordable and reasonable cost,", enacted a series of reforms in its massive Medical Care Availability and Reduction of Error Act ("MCARE") of 2002. The language of MCARE reveals the legislature's intention that it provide for a prompt determination of litigation and fair compensation for injuries

\footnotetext{
* Candidate for Juris Doctorate, University of Pittsburgh School of Law, May 2006. I would like to thank George C. Werner Jr. for his guidance and support on this note. In addition, I would like to thank the Honorable Thomas K. Kistler for the clerkship opportunity he extended to me in the first summer of law school, during which I was initially ex posed to th is statute. Finally, I would like to thank Melissa A. Brooks for her support and understanding during the drafting of this note. All mistakes are mine alone.

1. See Beth Cohan, Doctor Leaving Pennsylvania for Lower Insurance, The LANSDALE ReP. (Lansdale, Pa.), Aug. 11, 2004, available at http://www.carh.net/pdfs/MDLeavingPA_081104.pdf; Christopher Snowbeck, Insurance Cost Rise has Little Impact; Doctors Not Fleeing Malpractice Rates, Pittsburgh Post-GaZette, Nov. 11,2001, at B8, available at http://www.post-gazette.com/healthscience/ 200111 premiumshealth2p2.asp; see also RANDALl R. BovbJerg \& ANNA BARTow, UndERstanding Pennsylvania's Medical Malpractice Crisis: Facts about Liability Insurance, the Legal System And Health CARE In AMERICA 12-14 (2003), available at http://www.medliabilitypa.org/research/ report0603/UnderstandingReport.pdf. Butsee Public Citizen, The Facts about Medical Malpractice in Pennsy lvania (2004), available at $\mathrm{http} / /$ www.citizen.org/documents/PA_MedMal_Rpt.pdf (arguing against the existence of any current medical malpractice crisis).

2. See BovbJerg \& BArtow, supra note 1, at 5; see also Cohan, supra note 1. But see

Public Citizen, supra note 1 (arguing no mass exodus of Pennsylvania doctors has been observed).

3. See BovbJerg \& Bartow, supra note 1, at 5.

4. 40 Pa. Cons. Stat. AnN. $§ 1303.102$ (West Supp. 2005).
} 
resulting from medical negligence ${ }^{5}$ by overhauling the manner in which the law and medical professionals and patients interact. As its name indicates, one major thrust of MCARE addresses and sets forth procedures to reduce one reputed source of the medical malpractice crisis: physician error. MCARE attempts to achieve this objective through mandatory reporting procedures and record-keeping that require enhanced scrutiny of patient safety. ${ }^{6}$ In addition to emphasizing tools to police physician error and increase patient safety, MCARE reforms various legal aspects of medical malpractice litigation. Such changes include codifying a statute of repose ${ }^{7}$ and establishing new procedures regarding awarding damages, particularly punitive damages. ${ }^{8}$ One seemingly innocuous change now spawning considerable litigation in Pennsylvania trial courts establishes a standard setting forth the minimum qualifications necessary for medical experts testifying to a standard of care in a medical malpractice action. ${ }^{9}$ This new standard is codified in Section 512. ${ }^{10}$

Section 512 displaces, at least in some instances, the discretionary common law standard that governed the admissibility of expert testimony. Although Section 512 sets forth new qualifications a testifying physician must satisfy, the precise impact of this standard remains uncertain as judicial analysis of Section 512 and its statutory language is in its infancy. This note focuses upon the relatively undeveloped case law regarding the statutory language of Section 512. This note intends to introduce and resolve, consistent with Pennsylvania law, the significant current and future statutory issues associated with Section 512. Specifically, Part II of this comment will examine the background of Section 512, including the statutory language, its policy and the legislative history, to conclude that basic rules of statutory construction establish a legislative intent to enact a stricter standard with heightened qualifications for medical experts. Part III will address the proper resolution, consistent with legislative intent, of currently litigated issues, including the timing of the qualification requirement and its applicability to physician defendants. Part IV will forecast future issues involving unresolved statutory terms to suggest that a relatively narrow interpretation of these terms is required to preserve their plain meaning and effectuate the intent of the legislature. Part V will examine the role of the trial court's discretionary

See id

6. See generally id. $\S \S 1303.301-1303.314$.

7. Id.

8. $\quad$ See id. $\S 1303.505$.

9. See id. $\$ 1303.512$.

10. See id. 
bypass of the statutory requirements to conclude that the trial court must limit its discretion to circumstances where Section 512 operates to preclude experts unjustly or unfairly. Part VI will conclude that Section 512 achieves the intent of the legislature.

\section{BACKGROUND OF SECTION 512}

\section{A. Statutory Language of Section 512}

Integral to a proper statutory analysis is the language of the statute in question. Section 512, entitled “Expert Qualifications," follows in full below:

(a) GENERAL RULE.-No person shall be competent to offer an expert medical opinion in a medical professional liability action against a physician unless that person possesses sufficient education, training, knowledge and experience to provide credible, competent testimony and fulfills the additional qualifications set forth in this section as applicable.

(b) MEDICAL TESTIMONY.-An expert testifying on a medical matter, including the standard of care, risks and alternatives, causation and the nature and extent of the injury, must meet the following qualifications:

(1) Possess an unrestricted physician's license to practice medicine in any state or the District of Columbia.

(2) Be engaged in or retired within the previous five years from active clinical practice or teaching.

Provided, however, the court may waive the requirements of this subsection for an expert on a matter other than the standard of care if the court determines that the expert is otherwise competent to testify about medical or scientific issues by virtue of education, training or experience.

(c) STANDARDOF CARE.- - In addition to the requirements set forth in subsections (a) and (b), an expert testifying as to a physician's standard of care also must meet the following qualifications:

(1) Be substantially familiar with the applicable standard of care for the specific care at issue as of the time of the alleged breach of the standard of care.

(2) Practice in the same subspecialty as the defendant physician or in a subspecialty which has a substantially similar standard of care for the specific care at issue, except as provided in subsection (d) or (e).

(3) In the event the defendant physician is certified by an approved board, be board certified by the same or a similar approved board, except as provided in subsection (e).

(d) CARE OUTSIDE SPECIALTY.-A court may waive the same subspecialty requirement for an expert testifying on the standard of care for the diagnosis or treatment of a condition if the court determines that:

(1) the expert is trained in the diagnosis or treatment of the condition, as applicable; and

(2) the defendant physician provided care for that condition and such care was not within the physician's specialty or competence. 
(e) OTHERWISE ADEQUATE TRAINING, EXPERIENCE AND KNOWLEDGE.-A court may waive the same specialty and board certification requirements for an expert testifying as to a standard of care if the court determines that the expert possesses sufficient training, experience and knowledge to provide the testimony as a result of active involvement in or full-time teaching of medicine in the applicable subspecialty or a related field of medicine within the previous five-year time period. ${ }^{11}$

Section 512 is structured as two interrelated standards. Initially, subsections (a) and (b) establish a standard requiring all medical experts to satisfy minimal qualification criteria, regardless of the nature of the medical expert's testimony. ${ }^{12}$ Following these general requirements, the legislature set forth a waiver provision affording a trial judge a discretionary bypass of the statutory qualification requirements. ${ }^{13}$ Subsection (c) establishes a standard that is relevant exclusively when a medical expert is testifying to a physician's standard of care. ${ }^{14}$ Accordingly, an expert addressing the standard of care in a medical malpractice action must satisfy the requirements of subsections (a), (b) and (c). ${ }^{15}$ The discretionary waiver of the subsection (c) requirements is set forth in subsections (d) and (e). ${ }^{16}$

\section{B. Rules of Statutory Construction}

The Pennsylvania Statutory Construction Act establishes a hierarchy of the canons of statutory construction. ${ }^{17}$ The foremost objective of statutory construction and interpretation is determining and effectuating legislative intent. ${ }^{18}$ The Act further instructs that every statute be construed to give effect to all of the statutory provisions. ${ }^{19}$ When the language of the statute is free from ambiguity, the Act provides that the plain meaning of the statute prevails over any attempt to discern and pursue the spirit of the law..$^{20}$ In the event the words of the statute are not explicit, the legislative intent may be gleaned from

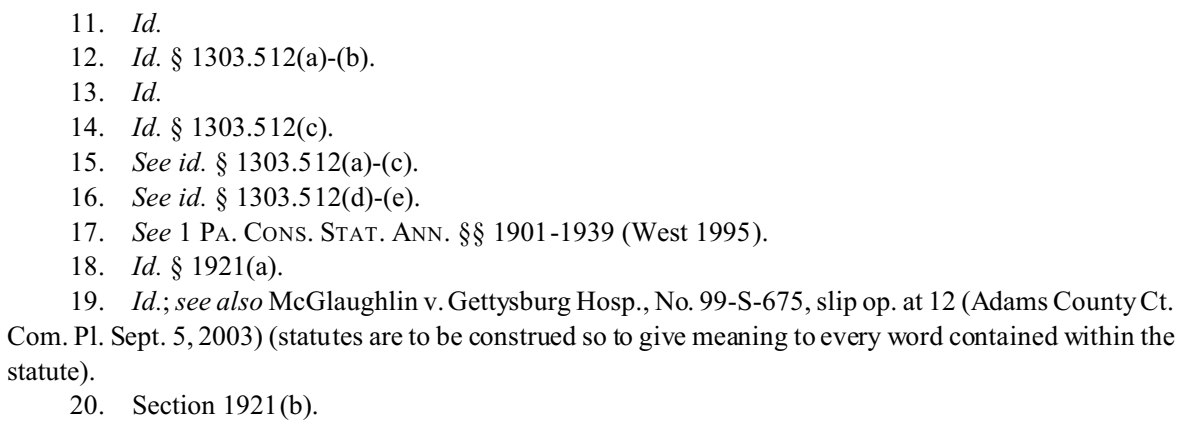


factors including the objective of the statute, the consequences of a particular interpretation, and the legislative history surrounding the enactment of the statute. ${ }^{21}$ In addition, the preamble and title of the statute may be considered in its construction..$^{22}$

The Act codifies appropriate presumptions when ascertaining legislative intent, including that the legislature did not intend an absurd or unreasonable result. ${ }^{23}$ Case law further instructs that a modification in the language of a proposed law by the legislature is indicative of a change in the legislature's admitted intent. ${ }^{24}$ The Act also sets forth rules to aid in the interpretation of statutory provisions. Rules relevant to this analysis include that words are to be construed according to their "common and approved usage," and "technical words and phrases ... [that] have acquired a peculiar and appropriate meaning or are defined in this part, shall be construed according to such . . . meaning. $" 25$

\section{Policy Intent of Statute}

The declaration of policy that prefaces MCARE illustrates the legislature's concern to forge a working balance within the healthcare system between fair compensation for parties suffering injury from medical negligence and the availability of high quality medical care. ${ }^{26}$ The legislature further recognized that maintaining quality medical care required the availability of affordable malpractice insurance for medical professionals. ${ }^{27}$ At the time of MCARE's passage, skyrocketing insurance premiums had spawned a widely recognized health care crisis within Pennsylvania. ${ }^{28}$ MCARE was one response by the legislature to ameliorate that crisis. ${ }^{29}$ Recognizing the legislature's concern with the current state of health care litigation, both trial courts and the Pennsylvania Superior Court have concluded that Section 512 represents a more restrictive standard than the

21. Id. §1921(c)(1)-(c)(8).

22. Id. § 1925.

23. Id. § 1922(a).

24. McGlaughlin, No. 99-S-675, at 12.

25. Section 1903(a).

26. See 40 Pa. Cons. Stat. Ann. § 1303.102 (West Supp. 2005).

27. See id.

28. See Asher Hawkins, Pa. Judges to Analyze Med Mal Litigation Changes, 231 The Legal Intelligencer, No. 56, at 3 (quoting Pennsylvania Supreme Court Chief Justice Ralph J. Cappy that "a recognized crisis in the medical malpractice area" exists); McGlaughlin, No. 99-S-675, at 9.

29. McGlaughlin, No. 99-S-675, at 9-10. 
previous, broad common law standard.$^{30}$ Accordingly, Section 512 is intended to narrow the field of qualified experts, with the result of limiting the admissibility of expert testimony in medical malpractice actions. ${ }^{31}$

\section{Legislative History}

The legislative history of Section 512 is generally unrevealing. The legislation later enacted as MCARE was conceived as House Bill 1802 on June 19, 2001.32 At the time of the introduction of the bill, no reference to medical expert qualifications existed..$^{33}$ A later draft, amended January 29 , 2002, included Section 828-A which addressed medical expert qualifications. $^{34}$ Although the language of the enacted statute essentially tracks this draft version, two minor variations are materially significant. ${ }^{35}$ Under the draft version of now codified subsection (b), the legislature required an expert to be "engaged in active clinical practice or teaching." 36 The February 12, 2002 amended version modified this requirement to permit an expert to "be engaged in or retired within the previous five years from active clinical practice or teaching" to testify. ${ }^{37}$ The January 29,2002 draft version also permitted the trial court to waive the statutory requirements now codified in subsection (c) if the trial court found that the expert possessed sufficient "experience or knowledge ... a a result of active involvement in the practice or full-time teaching of medicine within the five-year period before the incident giving rise to the claim. ${ }^{, 38}$ The February 12, 2002 amended version stripped the language "before the incident giving rise to the claim" from the legislation. ${ }^{39}$ The legislature ultimately adopted the February 12, 2002 version

30. See Wexler v. Hecht, 847 A.2d 95, 103 (Pa. Super. Ct. 2004) (recognizing that $\S 512$ imposes new requirements); McGlaughlin, No. 99-S-675, at 10; see also Spotts v. Small, 61 Pa. D. \& C.4th 225, 235 (Lancaster County Ct. Com. Pl. 2003).

31. Gartland v. Rosenthal, 850 A.2d 671, 675 (Pa. Super. Ct. 2004); Weiner v. Fisher, 67 Pa. D. \& C.4th 1, 10 (Phila. County Ct. Com. Pl. 2004).

32. H.B. 1802, Gen. Assem., 2001 Sess. (Pa. 2001), available athttp://www.legis.state.pa.us/WU01/ LI/BI/BT/2001/0/HB1802P2317.htm.

33. Id.

34. H.B. 1802, Gen. Assem., 2001 Sess. § 828-A, at 105 (Pa. 2001) (as amended Jan. 29, 2002), available at http://www.legis.state.pa.us/WU01/LI/BI/BT/2001/0/HB1802P3202.htm.

35. See id. at 105-06; McGlaughlin, No. 99-S-675, at 10-11.

36. H.B. $1802 \S 828-A$, at 105 (as amended Jan. 29, 2002).

37. H.B. 1802, Gen. Assem., 2001 Sess. § 512, at 100 (Pa. 2001) (as amended Feb. 12, 2002), available at http://www.legis.state.pa.us/WU01/LI/BI/BT/2001/0/HB1802P3320.htm.

38. H.B. $1802 \S 828$-A, at 105 (as amended Jan. 29, 2002).

39. H.B. $1802 \S 512$, at 101-02 (as amended Feb. 12, 2002). 
of the expert qualification statute on March 20, 2002, to take effect sixty days later. $^{40}$

\section{Currently Litigated Issues}

\section{A. Timing of Qualification Requirement}

One issue critical to interpreting Section 512 is resolving the timing of its application, namely whether a medical expert must possess the requisite qualifications at the time of the incident giving rise to the claim or at the time of testimony during the trial. ${ }^{41}$ Pennsylvania trial courts have split on the timing of the application of subsection (b) $(2),{ }^{42}$ and the Superior Court has yet to provide guidance, although the question of timing is currently on appeal. ${ }^{43}$

Initially, challenges to the timing of the application of Section 512 were directed to the entire MCARE act. ${ }^{44}$ These early arguments focused on the applicability of MCARE to causes of action arising prior to its enactment. At

40. See 2002 Pa. Laws $13, \S \S 512,5108$.

41. See Weiner v. Fisher, 67 Pa. D. \& C.4th 1 (Phila. County Ct. Com. Pl. 2004); McGlaughlin v. Gettysburg Hosp., No. 99-5-675 (Adams County Ct. Com. Pl. Sept. 5, 2003); see also Spotts v. Small, 61 Pa. D. \& C.4th 225 (Lancaster County Ct. Com. P1. 2003). Another currently litigated issue is the constitutionality of Section 512. McGlaughlin v. Gettysburg Hosp., 63 Pa. D. \& C.4th 504, 507 (Adams County Ct. Com. Pl. 2003). The constitutional challenges take two forms: claims that Section 512 violates equal protection and substantive due process and claims that Section 512 improperly infringes upon the exclusive rule-making authority vested in the Pennsylvania Supreme Court under Art. I, thus violating the separation of powers. Id. Pennsylvania trial courts have unanimously rejected equal protection claims. Id. at 507-08; Weiner, $67 \mathrm{~Pa}$. D. \& C.4th at 25-33. Recognizing the strong presumption of the constitutionality of legislation, Pennsylvania trial courts have concluded that when applying a rational basis test, the distinction in treatment between medical experts and other experts established by Section 512 is permissible because the state has a legitimate interest in reducing the costs of medical malpractice insurance. Weiner, $67 \mathrm{~Pa}$. D. \& C.4th at 31-33. Pennsylvania trial courts have likewise unanimously rejected claims alleging usurpation by the legislature of supreme court rule-making authority, instead casting witness competency statutes as evidentiary rather than procedural rules. Id. at 21-25; McGlaughlin, $63 \mathrm{~Pa}$. D. \& C.4th at 507-12. This holding is consistent with sister state statutes which characterize their medical expert competency statutes as rules of evidence. See, e.g., N.C. Gen. Stat. § 8C-1, R. 702 (2003) (expert competency statute codified in rule of evidence); McCrory v. State, 423 N.E.2d 156, 159 (Ohio 1981) (recognizing that the expert competency statute was incorporated into the Ohio Rules of Evidence). Based on the lack of disagreement among trial courts, and the relative weakness of the constitutional claims against Section 512, it is unlikely an appellate court will find Section 512 unconstitutional.

42. Compare Spotts, 61 Pa. D. \& C.4th 225 (holding timing of qualification requirement is at breach) with McGlaughlin, No. 99-S-675 (holding timing of qualification requirement is at testimony).

43. See Mc Glaughlin, 63 Pa. D. \& C.4th at 512-13 (granting an interlocutory appeal to the Superior Court for resolution of the timing issue).

44. Callari v. Rosenwasser, 63 Pa. D. \& C.4th 366, 372-73 (Phila. County Ct. Com. Pl. 2003); Estate of Kusinko v. Cherry, No. 2000-2281, slip op. at 8 (Centre County Ct. Com. Pl. Dec. 31, 2003). 
least two trial courts considered these arguments, and both held that because MCARE applied to the testimony of the expert, which occurred at a time following the enactment of MCARE, MCARE generally, and Section 512 specifically, applied to cases whose cause of action arose prior to the enactment of MCARE. ${ }^{45}$ Thus, at this primitive stage of first impression of Section 512, it appears that trial courts understood Section 512 to apply at the time of testimony or, at the earliest, the time of the expert's report, rather than the time of breach. As litigants refined their arguments regarding the timing of Section 512, the focus shifted from the applicability of Section 512, and MCARE as a whole, to whether the qualification requirements of Section 512 applied at the time of testimony or breach.

While the issue of the timing of the application of Section 512 extends to nearly all of its subsections, current litigation is focused on subsection (b)(2) ${ }^{46}$ which requires that an expert "be engaged in or retired within the previous five years from active clinical practice or teaching." ${ }^{47}$ Depending on the answer, the relevant timeframe from which to measure the "active" or "teaching" requirement is five years from the date of testimony or five years from the date of breach. Regarding the timing of other subsections of Section 512 , subsection (b)(1) has yet to be litigated because medical professionals often remain licensed long after they retire from active service, ${ }^{48}$ and thus subsection (b)(2) tends to be the limiting provision of that subsection. Subsection (c)(1) mandates measuring from the date of breach; however, the subspecialty requirement in (c)(2) and the board certification requirement in (c)(3) contain no such instruction. ${ }^{49}$ The subsection (e) requirement concerning active practice or teaching likewise lacks a provision addressing timing. ${ }^{50}$

\section{Timing of Section 512(b)(2)}

In concluding that the relevant timing for the application of subsection (b)(2) is the incident giving rise to the claim, the first reported Pennsylvania trial court to directly respond to this issue determined that the principles of

\footnotetext{
45. Callari, 63 Pa. D. \& C.4th at 375; Estate of Kusinko, No. 2000-2281, at 8-10.

46. See, e.g., Spotts, 61 Pa. D. \& C.4th at 233-40.

47. 40 Pa. Cons. Stat. AnN. $§ 1303.512$ (b)(2) (West Supp. 2005).

48. See Spotts, 61 Pa. D. \& C.4th at 230 (noting that the expert had retired from practice but maintained his current physician license by attending continuing education classes).

49. See § 1303.512(c)(1)-(c)(3).

50. Id. $\S 1303.512(\mathrm{e})$.
} 
statutory interpretation supported this result. ${ }^{51}$ The trial court noted a lack of a clear legislative intent regarding the timing of the application of Section $512 .^{52}$ The trial court reasoned that although subsection (c)(1) specifically utilized "as of the time of the alleged breach" language, its omission from other relevant sections of the statute did not prohibit the trial court from construing such a timing requirement as consistent with the statute. ${ }^{53}$ In support of this construction, the trial court referenced several sister state statutes which explicitly set forth that the qualifications of a medical expert should be determined at the time of breach. The court rejected drawing any inferences from the statutory language written in the present tense, such as "expert testifying." ${ }^{4}$ Upon these findings, the trial court stepped outside the statutory language and elaborated that a sound policy required the application of Section 512 at the time of the alleged breach. ${ }^{55}$

In direct contrast to the analysis above, two Pennsylvania trial courts have held that determining a medical expert's qualifications under subsection (b)(2) should occur at the time of testimony. ${ }^{56}$ These courts have premised their opinions on the statutory language and legislative history of MCARE and Section 512. ${ }^{57}$ In support of this construction, one trial court paralleled the rules addressing general witness competency to subsection (b)(2), which it deemed to address expert competency, to conclude that witness competency in general is determined at the time of trial. ${ }^{58}$ Both trial courts presented several policy considerations that favored applying subsection (b)(2) at the time of testimony. ${ }^{59}$

Recently, the Pennsylvania Superior Court sided with the reasoning of the latter trial courts, holding that Section 512 required that a medical expert's qualifications be measured from the time of the expert's testimony rather than the time of the alleged breach. ${ }^{60}$ In its initial opinion addressing the proper

51. Spotts, 61 Pa. D. \& C.4th at 235-37.

52. Id. at 236 .

53. Id. Adding words and phrases to aid in the interpretation of a statute is permissible when the words and phrases do not conflict with the obvious purpose or intent of the statute and do not affect the scope and operation of the statute. 1 PA. Cons. STAT. ANN. § 1923(c) (West 1995).

54. Spotts, 61 Pa. D. \& C.4th at 238-39.

55. Id. at 236 .

56. McGlaughlin v. Gettysburg Hosp., No. 99-S-675, slip op. at 16 (Adams County Ct. Com. Pl. Sept. 5, 2003); Weiner v. Fisher, 67 Pa. D. \& C.4th 1, 11 (Phila. County Ct. Com. Pl. 2004).

57. McGlaughlin, No. 99-S-675, at 8-13; Weiner, 67 Pa. D. \& C.4th at 11-15.

58. Mc Glaughlin, No. 99-S-675, at 14.

59. Id. at 14-15; Weiner, 67 Pa. D. \& C.4th at 14-15.

60. Weiner v. Fisher, 871 A.2d 1283, 1288 (Pa. Super. Ct. 2005); see also Bethea v. Phila. AFL-CIO Hosp. Ass'n, 871 A.2d 223, 226 (Pa. Super. Ct. 2005). 
time for measuring Section 512 requirements, the court held, without any analysis, that Section 512 required a medical expert to qualify at the time of testimony. ${ }^{61}$ Several weeks later, the court fully articulated its reasoning regarding the Section 512 timing issue in an unrelated opinion. ${ }^{62}$ The court concluded that the plain language of Section 512 indicated an unambiguous legislative intent to apply the Section 512 requirements at the time of the expert's testimony. ${ }^{63}$ The court commented that such an interpretation comported with sound medical policy, ${ }^{64}$ although the court acknowledged that application of this interpretation in certain circumstances might work an unfair, and likely unanticipated, result. ${ }^{65}$

\section{i. Statutory Language}

The plain language of the statute provides insight into the timing issue. As noted above, subsection (b)(2) is written in the present tense. ${ }^{66}$ Subsection (b)(2) requires that an expert witness "testifying on a medical matter ... [b]e engaged in or retired within the previous five years from active clinical practice. ${ }^{977}$ There is no statutory language in the past tense demonstrating that the statute contemplates measuring an expert's qualifications in the past. ${ }^{68}$ Although one trial court rejected this observation of grammar as simply describing the reliability rather than the timing of the requirements ${ }^{69}$ other trial courts have not dismissed the language so casually. ${ }^{70}$ In addition, the Pennsylvania Superior Court concluded that, upon its examination of the plain language of subsection (b)(2), it appeared unambiguous that subsection (b)(2) applies only in the present tense. ${ }^{71}$ The legislature's use of the present tense in subsection $(b)(2)$ is indicative of its intent that an expert must satisfy Section 512 at the moment the expert testifies. ${ }^{72}$ To conclude otherwise would require a court to look past the plain language in violation of the rules of

61. Bethea, 871 A.2d at 226.

62. Weiner, 871 A.2d at $1286-88$.

63. Id. at $1286-87$.

64. Id. at 1287.

65. Id. at 1288 n. 4 .

66. Id. at 1286

67. 40 Pa. Cons. Stat. AnN. $§ 1303.512$ (b)(2) (West Supp. 2005).

68. Weiner, 871 A.2d at 1286.

69. Spotts v. Small, 61 Pa. D. \& C.4th at 225, 238-39 (Lancaster County Ct. Com. Pl. 2003).

70. See McGlaughlin v. Gettysburg Hosp., No. 99-S-675, slip op. at 13 (Adams County Ct. Com. Pl. Sept. 5, 2003).

71. Weiner, 871 A.2d at $1286-87$.

72. Id. 
statutory interpretation. ${ }^{73}$ Other jurisdictions, citing common usage and plain language rules of construction, have reached a similar conclusion, reasoning that use of the present tense in medical expert qualification statutes implicated the time of testimony as the relevant timeframe for satisfying the statute. ${ }^{74}$

\section{ii. Legislative History}

The legislative history of MCARE and Section 512 is not entirely unclear regarding the subject of timing. Most telling is the legislature's removal of the language "before the incident giving rise to the claim" from subsection (e). ${ }^{75}$ This amendment demonstrated a rejection on the part of the legislature to define the timing of the requirements of subsection (e) according to the date of the incident. ${ }^{76}$ However, the legislature did not completely eliminate the "incident giving rise to the breach" language, as it left intact subsection (c)(1). Inasmuch as the legislature imposed the "breach" language in subsection (c)(1), but declined to use or withdrew the "breach" language elsewhere, this construction evinces a legislative intent not to focus the application of (b)(2) at the time of breach. ${ }^{77}$ The Pennsylvania Superior Court noted that the presence of the "breach" language in subsection (c)(1) and the conspicuous absence of the "breach" language from subsection (b)(2) evinced a legislative intent to focus subsection (b)(2) at the time of the expert's testimony. ${ }^{78}$

The only other amendment made to the original draft of Section 512 substantiates this conclusion. The second change initiated by the legislature involved modifying the language in subsection (b)(2) to "being engaged in or retired within the previous five years from active clinical practice." $"$ The resulting language in subsection (b)(2) mirrored in effect the requirements set forth in subsection (e), the very subsection where the legislature removed the reference to timing at the "date of the incident giving rise to the claim." ${ }^{80} \mathrm{~A}$ consistent reading of the similarly worded requirements in subsections (b)(2)

73. $I d$.

74. See Kurlanskyv. Blythe, 2004-Ohio-766, at 19 (Ohio. Ct. App. Feb. 20, 2004) (collecting lower court cases). But see Crosswhite v. Desai, 580 N.E.2d 1119, 1124-25 (Ohio. Ct. App. 1989) (cautioning that a strict grammarian response to an expert competency statute might subvert its purpose).

75. See supra notes 25-26.

76. McGlaughlin v. Gettysburg Hosp., No. 99-S-675, slip op. at 12 (Adams County Ct. Com. Pl. Sept. 5, 2003).

77. Id. at 12-13; Weiner v. Fisher, 67 Pa. D. \& C.4th 1, 18-19 (Phila. County Ct. Com. Pl. 2004).

78. Weiner v. Fisher, 871 A.2d 1283, 1287 (Pa. Super. Ct. 2005).

79. 40 Pa. Cons. Stat. AnN. $§ 1303.512$ (b)(2) (West Supp. 2005).

80. McGlaughlin, No. 99-S-675, at 12. 
and (e) requires the same timing of application. ${ }^{81}$ Since the legislature rejected the time of breach for subsection (e), it would likewise do so for subsection (b)(2). ${ }^{82}$ If the legislature intended otherwise, it would have simply inserted the "timing" language when it modified subsection (b)(2). For a court to prescribe such a requirement now under the guise of its powers of statutory construction would therefore be improper under Pennsylvania law.

\section{iii. Policy Rationale}

The policy rationale cited by the trial court that held that the time of breach is the relevant time to apply Section 512 makes the common sense observation that the timing of the statute's application at the breach would ensure that the expert testifying is familiar with the standard of care required at that period in time as required under subsection (c)(1). ${ }^{83}$ A substantial amount of time often elapses between the breach of care and trial, which increases the risk that a medical expert satisfying subsection (b)(2) qualifications at trial has little experience or familiarity with the standard of care at the time of the breach. ${ }^{84}$ The time of a trial is notoriously difficult to predict. Thus, relying on an unascertained date with no relation to the time of breach to test the competency of medical experts seems insensible. ${ }^{85}$

Hypothetical situations further illustrate the consequences of determining an expert's qualifications at testimony. A circumstance might arise where lengthy litigation would permit a medical expert who qualifies at trial to have been only enrolled in high school at the time of the breach. ${ }^{86}$ In addition, construing subsection (b)(2) to apply at trial might have the unusual consequence of precluding the defendant doctor from offering expert testimony on his own behalf. ${ }^{87}$ Furthermore, unavoidable delays in scheduling trials may have the unusual result of an expert, qualified at the time of disposition, becoming disqualified before trial due to the expiration of the

\footnotetext{
81. $I d$.

82. $I d$.

83. Spotts v. Small, 61 Pa. D. \& C.4th 225, 236-37 (Lancaster County Ct. Com. Pl. 2003).

84. Id.

85. Id. at 239 .

86. Grondin v. Curi, 817 A.2d 61, 74 (Conn. 2003).

87. Since the requirements of Section 512 apply to all experts regardless of whether the expert is testifying for the plaintiff or the defendant, a defendant physician that provides medical opinions at trial may be precluded if the expert retired from active medical care more than five years prior to testimony or otherwise fails to satisfy the Section 512 standard. Spotts, 61 Pa. D. \& C.4th at 237-38.
} 
five-year limit under subsection (b)(2). ${ }^{88}$ Such an interpretation might encourage delay tactics to prevent a plaintiff's retired expert from testifying at trial. ${ }^{89}$ The legislature could not have intended these results, and interpreting a statute to reach seemingly absurd conclusions does not comport with Pennsylvania law. ${ }^{90}$

One rationale offered in response is that applying Section 512 at trial permits the introduction of the most recent medical knowledge available for the fact finder to consider. ${ }^{91}$ Thus, on issues such as risk, causation, or the nature of the alleged injury, the fact finder is afforded the most current medical information. ${ }^{92}$ Furthermore, determining an expert's qualifications at trial permits a jury to assess the credibility of the expert at the time the expert testifies..$^{93}$ Determining the credibility of an expert in the present when his qualifications were measured sometime in the distant past would present an imposing challenge for a jury. ${ }^{94}$ This argument, however, is slightly undermined by subsection (c)(1), which requires the expert to possess familiarity with the standard of care as of the time of breach rather than the time of testimony. ${ }^{95}$ Thus, new information not known at the time of breach is irrelevant to an expert attempting to establish a breach of the standard of care at trial. ${ }^{96}$ Nevertheless, with regard to other issues, access to current medical knowledge will permit the fact finder to assess more accurately the circumstances in question. ${ }^{97}$ In addition, applying subsection (b)(2) at the time of trial ensures that testifying medical experts are currently qualified, which furthers the legislature's goal of prescribing a more stringent standard to medical experts. ${ }^{98}$

Finally, a hypothetical helps illustrate the shortcomings of the statute's application at the time of breach. One circumstance posed by a trial court involves a young child who suffers an act of negligence but waits to sue until

88. Weiner v. Fisher, 871 A.2d 1283, 1288 (Pa. Super. Ct. 2005).

89. Id.

90. See 1 Pa. Cons. Stat. AnN. § 1922(a) (West 1995).

91. McGlaughlin v. Gettysburg Hosp., No. 99-S-675, slip op. at 15 (Adams County Ct. Com. Pl. Sept. 5, 2003).

92. Weiner, 871 A.2d at $1287-88$.

93. Weiner v. Fisher, 67 Pa. D. \& C.4th 1, 14 (Phila. County Ct. Com. Pl. 2004).

94. Id. at 15 .

95. Spotts v. Small, 61 Pa. D. \& C.4th 225, 239 (Lancaster County Ct. Com. Pl. 2003).

96. Id.

97. Weiner, 871 A.2d at $1287-88$

98. McGlaughlin v. Gettysburg Hosp., No. 99-S-675, slip op. at 14-15 (Adams County Ct. Com. Pl. Sept. 5, 2003). 
reaching majority. ${ }^{99}$ A derivative of this hypothetical involves a patient who fails to discover an act of negligence, such as a sponge left in a body cavity, for many years. Locating an expert in active practice at the time of or the five years prior to the breach may be impossible in these situations. ${ }^{100}$ Thus, construing subsection (b)(2) to apply at breach can lead to absurd results not sanctioned by the legislature.

\section{iv. Sister State Statutes}

Any comparison between Section 512 and similar sister statutes is complicated by differences in purpose ${ }^{101}$ and statutory language. ${ }^{102}$ In defense of requiring an expert to meet the subsection (b)(2) standard at the time of breach, one trial court noted that several similar statutes explicitly mandated the applicable timeframe as the time of breach. ${ }^{103}$ However, the persuasiveness of this argument is diminished by the observation that these sister statutes, passed prior to Section 512, were available and likely examined by the legislature, which subsequently declined to add such language within subsection (b)(2). Furthermore, when addressing qualification statutes that fail to provide a timing, state courts have consistently not required an expert to satisfy the requisite qualifications at the time of breach. ${ }^{104}$ Thus, little authority exists to suggest reading in a time of breach requirement to subsection (b)(2) when language to that effect is absent.

Interestingly, several state courts have construed requirements within their qualification statutes that have no specific direction as to their timing to lack entirely any time restrictions. ${ }^{105}$ Doctrinally, sister state courts have reasoned that their respective legislatures, by specifying the relevant timing for some requirements of the statute, have evinced an intent to not prescribe

99. Id. at 15 n.9.

100. $I d$.

101. Compare Grondin v. Curi, 817 A.2d 61, 71-73 (Conn. 2003) (explaining a statute merely codifying the common law standard but not altering the scope of which experts may testify), and Endorf v. Bohlender, 995 P.2d 896, 903 (Kan. Ct. App. 2000) (explaining a statute intended to prevent the use of professional witnesses), with Gartland v. Rosenthal, 850 A.2d 671, 675 (Pa. Super. Ct. 2004) (recognizing that Pennsylvania's competency statute is intended to restrict which experts may testify).

102. Compare Ala. Code § 6-5-548 (2004), and Conn. Gen. Stat. Ann. § 52-184c (West 2004), and N.C. Gen. Stat. § 8C-1, R. 702 (2003), and Ohio. Rev. Code Ann. Evid. R. 601(D) (West 2000), with 40 Pa. Cons. Stat. AnN. § 1303.512 (West Supp. 2005).

103. Spotts v. Small, 61 Pa. D. \& C.4th 225, 238 (Lancaster County Ct. Com. Pl. 2003).

104. See Grondin, 817 A.2d at $73-74$ (collecting sister court cases that held that, in the absence of specific language to the contrary, qualifications are not measured at time of breach).

105. See Chapman v. Smith, 893 So. 2d 293, 297-98 (Ala. 2004); Grondin, 817 A.2d at 74. 
time restrictions where an express time requirement is omitted. ${ }^{106}$ However, sister courts have utilized this construction only in the context of board certification requirements. ${ }^{107}$ Equating the legislature's act of omitting a timing requirement from many of the subsections of Section 512 with an intent to establish no time restrictions makes little sense when considered within the larger scheme of the statute. For example, in accord with this rationale, the lack of a timing requirement in subsections (b), (c)(2), (c)(3), and (e) would indicate a legislative intent not to establish a timeframe for these requirements. Thus, it is conceivable that an expert who satisfies each of these various qualifications at some point during his life, except those under subsection (c)(3), is qualified to testify. Furthermore, construing the statute in this manner would provide no guidance for measuring the five-year requirement in subsections (b)(2) and (e). In fact, it would render the fiveyear requirement meaningless. This result is absurd and therefore unpersuasive. It is thus not surprising that no court or litigant in Pennsylvania has even argued such a construction.

\section{Impact of Subsection (B)(2) Timing upon Section 512 Timing}

In the interest of construing Section 512 as internally consistent, it is likely that a decision regarding the timing of subsection (b)(2) will impact the timing of the application of all subsections of Section 512. The alternative constructions illustrate the necessity of this conclusion. Construing the application of subsection (b)(2) at a different time than subsection (e), which shares a similar five-year active practitioner requirement, is illogical. In addition, the tense of the statutory text throughout Section 512 is consistent, ${ }^{108}$ implying a similar timing of application. Furthermore, to calculate subsection (b)(2) at breach while applying subsections (b)(1) or (c) at a time other than

106. See Grondin, 817 A.2d at 74; see also Chapman, 893 So. $2 \mathrm{~d}$ at 297-98.

107. See Grondin, 817 A.2d at 74; see also Chapman, 893 So. 2 d at 297-98. A Pennsylvania trial court that addressed a similar circumstance rejected this construction. Amato v. Ctr. Med. \& Surgical Assocs., No. 2002-357, 2004 WL 1987427 (Centre County Ct. Com. Pl. Aug. 10, 2004). The trial court, premising its opinion upon the plain language of $\S 512(\mathrm{c})$, concluded that subsection (c)(3) required current board certification. $I d$. at $* 6$. The court determined that an expert whose certification had lapsed failed to satisfy subsection (c)(3). Id. This holding is ultimately unhelpful, however, regarding the timing of application of $\S 512$ because the expert's certification expired long prior to the alleged breach. $I d$. at *1-2. Thus the trial court, in construing a requirement of current certification, did not determine whether subsection (c)(3) spoke to current certification as of the time of breach or current certification as of the time of testimony because the expert's certification was expired at either time. Id. at *1-2.

108. See 40 Pa. Cons. Stat. AnN. $§ 1303.512$ (West Supp. 2005). 
breach defeats the policy considerations that support the time of injury as the relevant time for determining an expert's qualifications. ${ }^{109}$ The relatedness of the policy concerns strengthens the argument that the timing debate over subsection (b)(2) will be determinative for the timing of other subsections.

\section{Conclusion}

The above analysis illustrates the tension between measuring a medical expert's qualifications at the time of breach and the time of testimony. The difficulty of determining the proper time of application is evident in the conflicting holdings of Pennsylvania trial courts. As illustrated by the opposing policy rationales, both approaches are imperfect and could lead to undesired or unintended results, thus exposing the inherent weaknesses in premising the construction of Section 512 solely upon policy concerns. ${ }^{110}$ Owing to the susceptibility of policy arguments to manipulation and widely varying interpretation, Pennsylvania law instructs a trial court to consider policy concerns second to the plain language of the statute. ${ }^{111}$ If the language is clear and unambiguous, the Act restricts a court from inquiring further unless the resulting construction is irrational or absurd. ${ }^{112}$ This rule is rooted in the notion that legislatures are better suited for making policy judgments than courts. Occasionally, the application of a statute to a particular individual may present consequences not intended by the legislature. However, as the Superior Court aptly noted, the correct forum for resolving such policy concerns is the legislature. ${ }^{113}$

Applying these principles to subsection (b)(2), the above analysis regarding the plain language of the statute makes clear that the requirements of Section 512(b)(2) should be measured at the time of the expert's testimony. Pennsylvania law instructs that, upon this determination, the inquiry into the statutory issue is concluded. However, even considering the additional sources from which courts may typically seek guidance regarding legislative intent, a similar conclusion is reached. Legislative history, for example, demonstrates an apparent intent of the legislature not to focus Section 512

109. Weiner v. Fisher, 871 A.2d 1283, 1286-87 (Pa. Super. Ct. 2005) (holding that Section 512(b) should be construed, in its entirety, to apply at the time an expert testifies).

110. See McGlaughlin v. Gettysburg Hosp., No. 99-S-675, slip op. at 14-15 (Adams County Ct. Com. Pl. Sept. 5, 2003); Spotts v. Small, 61 Pa. D. \& C.4th 225, 236-37 (Lancaster County Ct. Com. Pl. 2003).

111. See 1 Pa. Cons. Stat. AnN. § 1921(a)-(b) (West 1995).

112. See id. § 1922(1).

113. Dranzo v. Winterhalter, 577 A.2d 1349, 1355 (Pa. Super. Ct. 1990). 
requirements at the time of breach, with the exception of subsection (c)(1). In addition, although the application of the statute in some remote circumstances may cause an illogical or absurd conclusion, neither interpretation of the statute completely avoids illogical results. On the basis of these observations, the better reasoned approach to the interpretation of subsection (b)(2) and other subsections is determining a medical expert's qualifications at the time of testimony.

\section{B. Applicability to Non-Physician Defendants}

Any medical entity licensed by the Department of Health generally falls within the ambit of MCARE regulation. ${ }^{114}$ However, the text of subsections 512(a) and (c) makes clear that all medical experts rendering an opinion in medical malpractice actions against physicians must meet the minimum qualification criteria. ${ }^{115}$ The statute is silent as to whether malpractice actions involving hospitals, medical partnerships, nurses or non-physician defendants are subject to Section 512 scrutiny. It is unlikely that any definition of physician is broad enough to encompass hospitals or nurses, so the physician requirement may limit the applicability of Section 512. ${ }^{116}$ At present, at least one plaintiff has raised an argument that Section 512 applies solely to physicians and not to hospitals. ${ }^{117}$ In that case, the trial court made no explicit finding on that issue, and the Superior Court declined to address it, instead remanding the case to trial against the hospital on alternative grounds. ${ }^{118}$

Specifically under Section 512, the application of subsection (a) is premised upon an expert testifying in "a medical . . . action against a physician." "19 Likewise, subsection (c) specifies that experts testifying to a "physician's standard of care" must satisfy the additional qualification requirements set forth in subsection (c). ${ }^{120}$ In contrast, subsection (b) more

114. See Kristen R. Salvatore, Comment, Taking Pennsylvania Off Life Support: A Systems-Based Approach to Resolving Pennsylvania's Medical Malpractice Crisis, 109 Penn St. L. Rev. 363, 373 n.75 (2004).

115. 40 Pa. Cons. Stat. Ann. $\S 1303.512$ (a), (c) (West Supp. 2005).

116. See 1 Pa. Cons. Stat. Ann. $\S 1991$ (West 1995) (defining "physician" as a person licensed "to engage in the practice of medicine and surgery in any or in all of its branches"); Wexler v. Hecht, 847 A.2d 95,103 (Pa. Super. Ct. 2004) (stating that a podiatrist is not a physician because podiatrists are not licensed by the State Board of Medicine).

117. Campbell v. Attanasio, 862 A.2d 1282, 1289-90 (Pa. Super. Ct. 2004).

118. Id. at 1290 .

119. 40 Pa. Cons. Stat. AnN. § 1303.512(a) (West Supp. 2005).

120. Id. $\S 1303.512(\mathrm{c})$. 
broadly states "an expert testifying in medical matters" must satisfy subsections (b)(1) and (b)(2). ${ }^{12}$ It appears odd that the general expert qualification standard contained in subsection (a) would restrict its operation solely to physician defendants. In effect, the minimum qualification requirements for experts testifying against a defendant hospital would be less stringent than that of an expert testifying against an individual physician. Under such a reading, the admissibility of expert testimony regarding defendant hospitals would remain subject to the previous, more broad common law standard.

Even more curious is the legislature's decision to omit the "physician" requirement in subsection (b). ${ }^{122}$ It seems somewhat illogical to limit applicability of the general, common law "baseline" qualification requirements to experts testifying against physician defendants, but then demand medical experts satisfy the enhanced standard established in subsection (b) without regard to the type of defendant. The physician requirement for the application of subsection (c) is less troublesome in terms of logic. ${ }^{123}$ Both subsections (c)(2) and (c)(3) specify that the testifying medical expert have similar qualifications to the defendant physician. ${ }^{124}$ Since a hospital cannot be board certified or practice a substantially similar subspecialty, limiting subsection (c) to physicians is sensible.

The legislature's intent behind such a distinction depending on the defendant and its decision not to extend the codified standard in subsection (a) beyond physicians is not clear. The legislature intended MCARE to help ensure the affordability of malpractice insurance, ${ }^{125}$ and hospitals, much like physicians, have experienced increases in their liability insurance in recent years. ${ }^{126}$ However, perhaps this distinction is not so significant. Since subsection (a) is regarded as simply a restatement of the common law standard, ${ }^{127}$ physician and non-physician defendants are likely held to a similar standard regardless of whether the common law or subsection (a) is applied. Subsection (b) represented a departure from the common law, and its enhanced standard applies regardless of the identity of the defendant. ${ }^{128}$ As previously stated, subsection (c) primarily insures that a testifying physician

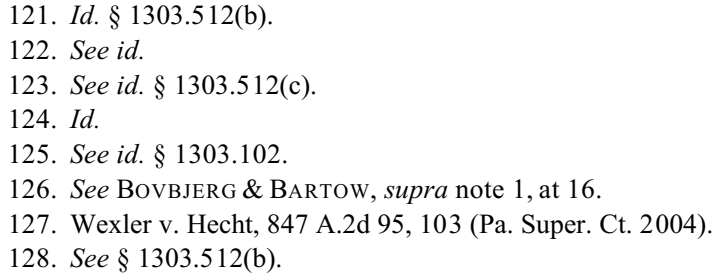


exhibit similar credentials to a defendant physician, and is mostly inapplicable for other types of defendants. ${ }^{129}$ The practical result under this analysis is that the admissibility of evidence at trial under either standard will be similar, except when subsection (c) is implicated.

Another possible explanation, previously raised on appeal but resulting in no decision, is the argument that no section of Section 512 is intended to apply to any medical defendants other than physicians. ${ }^{130}$ However, the lack of the physician-defendant restriction on subsection (b) would appear fatal to this argument, especially when considered in light of the rule of statutory construction that instructs every word in a statute should be given effect to the extent possible. ${ }^{131}$ Although a clear explanation for this distinction between physician and other defendants is unavailing, the result of the distinction is not absurd or unreasonable, so the clear, plain language of the statute should control. ${ }^{132}$ Accordingly, the physician requirement should limit the applicability of subsections (a) and (c) solely to experts testifying against physician-defendants.

\section{UnResolved Statutory Terms}

The case law of sister state statutes addressing the qualification of medical experts reveals that certain phrases and terms common to these statutes are frequently and repeatedly litigated. ${ }^{133}$ Since litigation in Pennsylvania regarding Section 512 essentially parallels that observed in states with previously enacted expert qualification statutes, it is likely arguments raised out of state will be repeated in Pennsylvania. ${ }^{134}$ Thus, once

129. See id. $\S 1303.512(\mathrm{c})$.

130. Campbell v. Attanasio, 862 A.2d 1282, 1289-90 (Pa. Super. Ct. 2004).

131. McGlaughlin v. Gettysburg Hosp., No. 99-S-675, slip op. at 9 (Adams County Ct. Com. Pl. Sept. 5, 2003).

132. See 1 Pa. Cons. Stat. Ann. § 1921(a) (West 1995).

133. See, e.g., Chapman v. Smith, 893 So. 2d 293 (Ala. 2004) (discussing board certification); Johnson v. Price, 743 So. 2d 436 (Ala. 1999) (discussing board certification requirement); Endorf v. Bohlender, 995 P.2d 896 (Kan. Ct. App. 2000) (discussing active clinical standard); Halloran v. Bhan, 683 N.W.2d 129 (Mich. 2004) (discussing board certification requirement); Hamilton v. Kuligowski, 684 N.W.2d 366 (Mich. Ct. App. 2004) (describing subspecialty requirement); Edwards v. Wall, 542 S.E.2d 258 (N.C. Ct. App. 2001) (discussing what activities satisfy the statutory requirement of "instruction of students"); Kurlansky v. Blythe, 2004-Ohio-766 (Ohio Ct. App. Feb. 20, 2004) (discussing active requirement); Debar v. Women \& Infants Hosp., 762 A.2d 1182 (R.I. 2000) (concluding that same subspecialty is not required in Rhode Island); Howell v. Baptist Hosp., No. M2001-02388-COA-R3-CV, 2003 Tenn. App. LEXIS 21 (Tenn. Ct. App. Jan. 14, 2003) (discussing specialty requirement).

134. Michigan is one example. Following the passage of Michigan's expert competency statute, the statute's constitutionality was challenged first in McDougall v. Schanz, 597 N.W.2d 148 (Mich. 1999), and 
current litigation focusing primarily on broad issues regarding the applicability of Section 512 is resolved, it is foreseeable that litigation in Pennsylvania will shift to focus upon the interpretation of key terms and phrases within the statutory text of Section 512. These key terms of interest include "board certification," "active clinical practitioner," "full-time," "teaching," and "same subspecialty."

\section{A. Board Certification}

Other states' case law has addressed several issues relating to the interpretation of the board certification requirement that may impact Pennsylvania litigation. Initially, it should be noted that specific text utilized in subsection (c)(3) that provides for the "same or similar" board certification likely avoids the issue resulting from a strict construction of the "same" board certification language. ${ }^{135}$ For example, one state supreme court held that its expert qualification statute, which required the same American board certification in the same specialty, precluded an expert certified by the American Board of Surgery from testifying against a physician certified by the American Osteopathic Board of Surgery. ${ }^{136}$ The court reasoned that, despite compelling policy arguments that the certification organizations had the same purpose, certified the same types of physicians, and had the same requirements, the plain language of the statute dictated the court's result. ${ }^{137}$ The "similar to" language in subsection (c)(3) likely affords a trial court some discretion to avoid this result in cases where the board certifications, although facially different, are essentially equal in quality. ${ }^{138}$

In early litigation following the enactment of MCARE, several Pennsylvania trial courts addressed the situation of an expert that lacked an identical board certification as the defendant physician. The trial courts quickly concluded that the plain language of subsection (c)(3) required preclusion of the expert's testimony. ${ }^{139}$ However, these early decisions did not

\footnotetext{
again in Tobin v. Providence Hospital, 624 N.W.2d 548 (Mich. Ct. App. 2001). Later litigation focused on the timing of the qualification requirements, see generally Halloran, 683 N.W.2d 129, and defining the specific meaning of the requirement of board certification, Tate v. Detroit Receiving Hosp., 642 N.W.2d 346 (Mich. Ct. App. 2002).

135. 40 Pa. Cons. Stat. Ann. § 1303.512(c)(3) (West Supp. 2005).

136. Johnson v. Price, 743 So. 2d 436, 438 (Ala. 1999)

137. Id. at 438-39.

138. The degree of relatedness necessary to trigger application of this standard has yet to be litigated.

139. Estate of Kusinko v. Cherry, No. 2000-2281, slip op. at 13 (Centre County Ct. Com. Pl. Dec. 31, 2003); Johnson v. Rybarcqyk, No. 98-06728, slip op. at 5-6 (Montgomery County Ct. Com. P1. May 31,
} 
contemplate the more complex problem of relevancy that will likely arise in future litigation.

\section{Relevancy of Board Certification}

One complexity litigated in other states involving the board certification requirement is the circumstance where the defendant physician possesses certification by multiple boards in one or more subspecialties. ${ }^{140}$ The question that follows is whether the testifying expert must possess board certification in each of the subspecialties as the defendant physician or just the relevant subspecialty. ${ }^{141}$ A related issue arises when a defendant doctor possesses board certification in a subspecialty, but the treatment at issue is unrelated to that certification. The issue thus becomes whether the expert must have any board certification in such situations.

Although no Pennsylvania case law has addressed this facet of the board certification requirement, sister jurisdictions having considered the issue have incorporated a relevancy standard. For example, one court has held that its expert competency statute did not require an expert to match exactly every board certification possessed by the defendant physician. ${ }^{142}$ The court reasoned that requiring an expert to possess board certification in an irrelevant specialty was an absurd result. ${ }^{143}$ Likewise, another state court stated in dicta that its board certification requirement should not be construed to require the expert to match a certification irrelevant to the treatment being litigated. ${ }^{144}$

The analysis of sister state courts of incorporating a relevancy requirement despite the lack of explicit language is persuasive. It seems illogical and unreasonable to demand that an expert match exactly all the board certifications possessed by the defendant physician when the treatment at issue does not implicate the credentials of the defendant physician. Requiring a plaintiff to find an expert capable of matching board certifications unrelated to the treatment at issue is a needless burden on the plaintiff and would hardly ensure MCARE's stated objective of providing efficient compensation for injured parties through the legal system. In addition, an implicit goal of Section 512 is insuring that experts testify only to matters in

2003).

140. See, e.g., Tate, 642 N.W.2d at 350.

141. $I d$.

142. $I d$.

143. $I d$.

144. Halloran v. Bhan, 683 N.W.2d 129, 131 n.5 (Mich. 2004). 
which they are qualified. Requiring a match of irrelevant board certification in no way furthers this objective. Therefore, a Pennsylvania court should construe the board certification requirement in subsection (c)(3) to apply only when the treatment at issue is related to the board certification possessed by the defendant physician.

\section{B. Same Subspecialty}

An expert testifying to a standard of care must satisfy subsection (c)(2), which provides that an expert must practice in the same subspecialty or a subspecialty with a substantially similar standard of care for the specific care at issue as the defendant physician. ${ }^{145}$ Subsection (c)(2) is unique amongst sister state competency statutes because it requires a higher standard of subspecialty, rather than just specialty. ${ }^{146}$ Thus, it would appear from the plain language that the legislature intended to enact a stricter standard than is commonly employed in competency statutes. However, subsection (c)(2) permits an expert practicing in a subspecialty with a substantially similar standard of care to testify, ${ }^{147}$ thus providing the trial judge some discretion in enforcing this requirement. Since the terms specialty and subspecialty are well defined in the medical field, litigation of this subsection will likely focus upon the permissible degree of similarity. Reported state case law is relatively unhelpful, as most litigation focuses upon attempts to construe the same specialty requirement in their respective qualification statutes to the higher standard of subspecialty, ${ }^{148}$ an irrelevant argument in Pennsylvania.

Several Pennsylvania trial courts have considered what categories of subspecialties might share a substantially similar standard of care so as to meet subsection (c)(2). ${ }^{149}$ Trial courts have found this requirement unsatisfied by a neurologist testifying to the standard of care applicable to an emergency room physician, a family practitioner and a radiologist; ${ }^{150}$ a pulmonology expert testifying to the standard of care applicable to a neurologist; ${ }^{151}$ and a

145. 40 Pa. Cons. Stat. AnN. $§ 1303.512$ (c)(2) (West Supp. 2005).

146. Compare id. with Mich. Comp. Laws AnN. $\$ 600.2169$ (West 2004), and Ala. Code § 6-5-548 (West 2004), and Conn. Gen. Stat. Ann. § 52-184c (West 2004).

147. Section 1303.512(c)(2).

148. See, e.g., Hamilton v. Kuligowski, 684 N.W.2d 366 (Mich. Ct. App. 2004); Debar v. Women \& Infants Hosp., 762 A.2d 1182 (R.I. 2000).

149. See infra notes 150-52.

150. McGlaughlin v. Gettysburg Hosp., No. 99-S-675, slip op. at 20-22 (Adams County Ct. Com. P1. Sept. 5, 2003).

151. Estate of Kusinko v. Cherry, No. 2000-2281, slip op. at 14 (Centre County Ct. Com. Pl. Dec. 31, 
podiatry expert testifying to the standard of care applicable to a practitioner of physical medicine. ${ }^{152}$ In the only reported case at the Superior Court addressing the degree of similarity necessary to satisfy the subspecialty requirement of subsection (c)(2), a trial court elected to admit the testimony of an expert who failed to meet the same subspecialty standard. ${ }^{153}$ Parsing the Superior Court opinion affirming the trial court's discretion under subsection (c)(2), it is evident that the trial court applied a rather stringent test of similarity. In the case, the defendant physician possessed certification in nephrology, as well as specialized training in internal medicine, and the expert possessed certification in internal medicine and critical care. ${ }^{154}$ The malpractice suit did not involve the defendant's care regarding nephrology, but rather concerned claims related to the defendant's alleged lack of care for failing to identify an airway obstruction. ${ }^{155}$ The treatment for such a condition implicated the defendant's knowledge of internal medicine. ${ }^{156}$ The expert testified only to the standard of care applicable to a physician with specialized training in internal medicine. ${ }^{157}$ Although the defendant and the expert practiced different subspecialties, they both possessed specialized knowledge of internal medicine, the specific care at issue. ${ }^{158}$ In effect, the trial court permitted testimony under the similar subspecialty exception when the standard of care of the subspecialty of the expert was essentially identical to the standard of care applicable to the treatment at issue provided by the defendant. Whether such a high degree of similarity would always be necessary is not yet clear.

Considering the legislature's decision to prescribe the high standard of subspecialty in conjunction with the Superior Court's recognition that Section 512 plainly prefers that a testifying expert satisfy the same-subspecialty requirement, ${ }^{159}$ a strict construction of this requirement should be enforced in Pennsylvania. Furthermore, trial courts have generally endorsed such a construction. ${ }^{160}$

2003).

152. Fuller v. Pa. Hosp., No. 1586, at *1-2 (Phila. County Ct. Com. Pl. 2003)

153. Herbert v. Parkview Hosp., 854 A.2d 1285, 1291-92 (Pa. Super. Ct. 2004).

154. $I d$.

155. $I d$.

156. Id. at 1293-94.

157. Id. at 1294 .

158. Id.

159. Id.

160. See, e.g., Estate of Kusinko v. Cherry, No. 2000-2281, slip op. at 14 (Centre County Ct. Com. Pl. Dec. 31, 2003) (finding that, although the expert and the defendant physician practiced the same 


\section{Active Clinical Practitioner}

The key phrase "active clinical practitioner" has generated significant litigation in sister states. ${ }^{161}$ Although the precise language in each state statute varies, the words "active" or "actual" and "clinical" are common amongst all the statutes of interest. ${ }^{162}$

\section{1. "Active"}

Examining first the "active" requirement, many state statutes define "active" or "actual" as a majority of professional time or fifty percent of professional time. ${ }^{163}$ State statutes lacking an express definition of these terms have also reasoned that a similar percentage of activity is necessary to satisfy the requirement. ${ }^{164}$ Since Section 512 likewise lacks any explicit direction as to the meaning of "active," the trial court may, in its discretion, determine what level of activity is sufficient to satisfy the "active" requirement. Such a finding should require at least a majority of time dedicated to activity as a clinical practitioner.

\section{2. "Clinical Practitioner"}

The "clinical practitioner" requirement ${ }^{165}$ has generated relatively diverse holdings regarding the scope of its definition. ${ }^{166}$ Beginning with the plain text of the phrase, medical dictionaries ascribe a narrow meaning to "clinical" to include "based on or pertaining to actual experience in the observation and treatment of patients."167 General dictionaries define "clinical" more broadly

specialty of internal medicine, their subspecialties of pulmonology and neurology lacked a substantially similar standard of care)

161. See Kurlansky v. Blythe, 2004-Ohio-766 (Ohio Ct. App. Feb. 20, 2004); see also Endorf v. Bohlender, 995 P.2d 896 (Kan. Ct. App. 2000) (hearing similar litigation on the phrase "actual clinical practice"); Edwards v. Wall, 542 S.E.2d 258 (N.C. Ct. App. 2001).

162. Compare N.C. Gen. Stat. § 8C-1, R. 702 (2003), and Kan. Stat. Ann. § 60-3412 (West 2005), with 40 Pa. Cons. Stat. Ann. § 1303.512 (West Supp. 2005).

163. N.C. Gen. Stat. § 8C-1, R. 702; Kan. Stat. AnN. § 60-3412.

164. See, e.g., Ohio Rev. Code Ann. Evid. R. 601(D) (West 2000)

165. Many sister state statutes employ the phrase "clinical practice" instead of clinical practitioner. However, the operative effect of the two phrases is identical.

166. Compare Endorf, 995 P.2d 896, with McCrory v. State, 423 N.E.2d 156, 159-60 (Ohio 1981).

167. Edwards v. Wall, 542 S.E.2d 258, 263 (N.C. Ct. App. 2001) (quoting an attorney's dictionary

of medicine cited in another case); see also Stedman's Medical Dictionary 362 (27th ed. 2000) 
to encompass activity beyond patient treatment, including "applying objective or standardized methods ... to the description, evaluation and modification of human behavior." 168 The plain text meaning of practitioner presents no conflict, as medical authority borrows the commonly understood definition of "one who practices a profession." 169 This definition is functionally similar to that of "practice," commonly used in place of the word practitioner within sister state competency statutes.

State courts conflict on which definition of "clinical" to endorse. One state court, in rejecting a proffered definition of "clinical" to include any medically related activity such as research, mentoring, consultation, and administrative activity, concluded that the medical definition of "clinical" should control. ${ }^{170}$ The court reasoned that the legislature intended the phrase "clinical practice," when used in a medically related statute, to reflect the commonly understood medical definition of "clinical practice." Thus, the court found actual clinical practice to pertain solely to actual patient care. ${ }^{171}$ Other state courts define the phrase "active clinical practice" more broadly to include any physician-specialist whose work was "so related or adjunctive to patient care." 172 This court determined that a physician who spent the majority of his time as the Director of Clinical Research for a drug manufacturer satisfied this requirement. ${ }^{173}$

One trial court in Pennsylvania has addressed the active clinical practitioner requirement. ${ }^{174}$ The trial court noted that the expert admitted that he had not treated his own patients or performed a surgery in the fifteen years preceding his testimony. ${ }^{175}$ The trial court examined the expert's current activities, which included conducting limited examinations of patients, although no official recording in the patient log occurred. ${ }^{176}$ The trial court found the expert's informal, unofficial visits to patients failed to satisfy the

(defining clinical as "related to the bedside of a patient" and "denoting the symptoms and course of a disease").

168. See In re Barnes, 510 N.E.2d 392, 397 (Ohio Ct. App. 1986) (quoting Webster's Third New INTERNATIONAL DiCTIONARY 423 (1971)).

169. Merriam Webster's Collegiate Dictionary 914 (10th ed. 1994) [hereinafter Merriam WEBSTER's].

170. Endorf v. Bohlender, 995 P.2d 896, 901-03 (Kan. Ct. App. 2000).

171. Id. at 901-02.

172. McCrory v. State, 423 N.E.2d 156, 160 (Ohio 1981).

173. Id. at $160-61$.

174. See Amato v. Ctr. Med. \& Surgical Assocs., No. 2002-357, 2004 WL 1987427 (Centre County Ct. Com. Pl. Aug. 10, 2004).

175. Id. at $* 1$.

176. Id. at *1-2. 
active clinical requirement. ${ }^{177}$ Although the trial court declined to specify what definition of "clinical" it endorsed and what level of activity would satisfy the active standard, underlying the trial court's reasoning is an apparent concern with the expert's long absence from actual patient care, thus implying the court's adoption of the narrower interpretation of "clinical." This reasoning is persuasive. Within the context of Section 512 and MCARE generally, which is primarily concerned with medical professionals, it seems reasonable to assume the legislature understood the common medical meaning ascribed to the term "clinical" and intended this meaning to prevail. Therefore, the medically sanctioned definition of "clinical" controls within Pennsylvania.

\section{Teaching}

The requirement of "teaching" is specified under both subsections (b)(2) and (e). ${ }^{178}$ It appears from the plain language of Section 512 that the legislature intended the teaching provision to permit the admission of testimony from medical professors and others not directly involved in patient care. ${ }^{179}$ The inquiry under the teaching requirement is best analyzed under a two-prong test. ${ }^{180}$ The first prong relates to the quality or nature of activities that satisfactorily fit within the requirement. The second prong involves determining the length of time an expert must spend in teaching-related activities to satisfy the standard. The statute provides no definition of "teaching," and little guidance for answering this inquiry. The common dictionary provides some insight, as it defines "teaching" as the "act, practice, or profession of a teacher." "181 A teacher is further defined as "one who instructs, especially one whose occupation is to instruct." 182 At least when regarding the timing prong of the teaching inquiry, it appears that an expert should spend at least a substantial time in teaching activities for an expert to be considered engaged in an "occupation of instruction." However, this definition provides little guidance in resolving what activities are appropriate under the nature of the activities prong in the context of medical teaching, an

177. Id. at *5.

178. 40 Pa. Cons. Stat. Ann. § 1303.512(b)(2), (e) (West Supp. 2005).

179. See id.

180. This test is merely a convenient method of organizing the analysis under this requirement suggested by the author. No court has specifically utilized this type of two-pronged test.

181. Merriam Webster's, supra note 169 , at 1209.

182. $I d$. 
inquiry further complicated by the divergence of instruction in medical school from traditional models of teaching. ${ }^{183}$

Little case law exists delineating precisely what type of activities qualify a medical expert under the "teaching" standard, and no sister state case law is directly on point. One state court engaged in a discussion of what type of teaching activities would satisfy its competency statute, which required an expert engage in the "instruction of students." constituted instruction of students, the court reasoned that formal lectures and the treatment of patients in the presence of residents, fellows and students met the instruction requirement. ${ }^{185}$ Addressing what types of activities fail under this standard, state courts have rejected the testimony of experts whose roles were primarily consulting or administrative, reasoning these activities diverged too far from actual medical practice. ${ }^{186}$ Regarding the timing prong, most state competency statutes establish specifically what amount of activity will satisfy their respective standard, generally requiring an expert to dedicate fifty percent or a majority of professional time in medical activities such as teaching. ${ }^{187}$ This amount of time corresponds with that imposed on the active requirement discussed above. ${ }^{188}$ Section 512 lacks specific language addressing timing, thus vesting this determination within the discretion of the trial court.

One Pennsylvania trial court has addressed the teaching standard under subsections (b)(2) and (e). ${ }^{189}$ Under the nature of the activities prong of the test posited above, the trial court made several findings of fact. The expert

183. Although medical school involves some classroom instruction, a substantial portion of the practice of medicine is taught and experienced beyond the classroom. See Harvard Medical School Years III \& IV, http://hms.harvard.edu/admissions/default.asp?page=years34 (noting that years three and four of medical school involve primarily clinical work). Expecting traditional notions of lectures, exams, regularly scheduled classes, meetings, projects and so forth as evidence that an expert satisfies the teaching standard may be inappropriate at times. In addition, faculty acting in a primarily administrative or in an advisory role further complicates this issue.

184. Edwards v. Wall, 542 S.E.2d 258, 261-62 (N.C. Ct. App. 2001).

185. Id. at 264

186. See Hunt v. Crossroads Psychiatric \& Psychological Ctr., No. 79120, 2001 Ohio App. LEXIS 5388 (Ohio Ct. App. Dec. 6, 2001). Although some state statutes lack a provision for permitting experts in the practice of teaching to testify, these states generally permit testimony under an expansive reading of the active clinical practice requirement. McCrory v. State, 423 N.E.2d 156, 158-61 (Ohio 1981).

187. See, e.g., Edwards, 542 S.E.2d at 261-62 (stating that an expert must dedicate a majority of professional time to the instruction of students).

188. See supra notes 163-64 (discussing the amount of time necessary to satisfy the active standard).

189. See Amato v. Ctr. Med. \& Surgical Assocs., No. 2002-357, 2004 WL 1987427 (Centre County Ct. Com. Pl. Aug. 10, 2004). 
ceased actively treating patients fifteen years prior to his testimony. ${ }^{190}$ The expert no longer formally lectured or published papers. ${ }^{191}$ Additionally, the expert's role at the medical school did not resemble that of a typical professor, as the expert conducted no evaluations or grading, lacked scheduled hours for instruction or office hours, and adhered to no established daily routine or schedule. ${ }^{192}$ In addition, although the expert met with students in committee meetings to discuss treatment options for patients, the expert bore neither direct responsibility nor oversight as to the treatment students then provided for patients. ${ }^{193}$ The trial court characterized the expert's interactions with students as merely informal mentoring, an activity short of satisfying the teaching requirement of subsection (b)(2). ${ }^{194}$

Regarding the amount of time spent in teaching activities, the trial court deemed that the expert independently failed this prong. ${ }^{195}$ The expert met informally with students, residents and fellows twice a week for a few hours as a member of a committee discussion. ${ }^{196}$ The court found that this amount of time fell short of that required under subsection (b)(2). ${ }^{197}$ Apparent from the trial court's opinion is that the teaching standard of subsection (b)(2) reflects an implicit requirement of active teaching, which the expert failed to satisfy. ${ }^{198}$ In addressing the standard for teaching under subsection (e), the trial court reasoned that this teaching standard was at least equally as stringent as that under subsection (b)(2), and thus concluded that the expert's "mentoring" activities fell short of full-time teaching. ${ }^{199}$

The reasoning of the Pennsylvania trial court regarding the teaching requirements of subsections (b)(2) and (e) is persuasive, and its findings comport with the plain language definition of teaching described above. Regarding the nature of the activities prong, the trial court expanded its inquiry beyond the traditional evidence of teaching such as lectures and exams to examine whether the expert treated patients in the presence of students, or

190. Id. at *1.

191. Id.

192. $I d$. at $* 2$.

193. Id. at *1-2.

194. Id. at *5-6.

195. $I d$. at *6 (noting that the expert's limited activities failed to satisfy an "active" teaching requirement).

196. Id. at *1-2.

197. Id. at *6.

198. Id.

199. Id. at * $5, * 7$. 
assisted residents and fellows with diagnosis and treatment schemes. ${ }^{200}$ The trial court correctly concluded that participating informally with no direct oversight failed to qualify the expert. ${ }^{201}$ Regarding the timing prong, meetings held twice a week for several hours could not constitute a majority of the expert's professional time, so the trial court correctly found the expert failed this inquiry as well. ${ }^{202}$ Thus, under the dual inquiry for the teaching requirement, the plain language of the teaching standard and case law require that an expert be employed in the occupation of teaching and dedicate at least a majority of professional time to teaching-related activities to satisfy subsections (b)(2) and (e).

Further complicating the teaching requirement is that the teaching requirement under subsection (e) is qualified by "full-time," but the teaching requirement under subsection (b)(2) lacks similar language. ${ }^{203}$ In the interest of consistency, the activities prong of the teaching requirement under subsection (e) will likely be construed identically to that under subsection (b)(2). How the added requirement of full-time modifies the timing prong of the teaching requirement is unclear. The most likely interpretation is that the "full-time" requirement will demand at least as stringent a standard for teaching as that under subsection (b)(2). ${ }^{204}$ It is possible the "full-time" qualifier may demand a more involved teaching regime for experts seeking qualification to testify under a subsection (e) waiver. ${ }^{205}$ However, because the plain meaning of teaching implies an occupation of teaching, most experts qualified to testify under the teaching requirement will be, in effect, engaged in full-time teaching activities.

\section{Trial Court Discretion}

Traditionally, Pennsylvania law vested significant discretion in the trial judge to determine the competency of witnesses and the admissibility of testimony. ${ }^{206}$ Section 512 preserves this discretionary role, albeit with some

200. See id. at *1-2 (noting a lack of actual patient care).

201. See id. at *5-6.

202. See id. at $* 2$.

203. 40 Pa. Cons. Stat. Ann. $\S 1303.512$ (b)(2), (e) (West Supp. 2005).

204. See Amato, 2004 WL 1987427 , at *5-7 (finding that an expert who failed to satisfy the teaching requirement in subsection (b)(2) likewise failed to satisfy the teaching requirement in subsection (e)).

205. See Weiner v. Fisher, 871 A.2d 1283, 1289-90 (Pa. Super. Ct. 2005) (noting that the full-time modifier to teaching in $\S 512(\mathrm{e})$ is more stringent than the standard for teaching demanded under $\S 512(b)(2))$.

206. Herbert v. Parkview Hosp., 854 A.2d 1285, 1294 (Pa. Super. Ct. 2004). 
important limitations and considerations..$^{207}$ The first provision addressing the discretion immediately follows subsection (b) and permits a trial court to waive the requirements of "this subsection" for an expert otherwise competent to testify on all matters except the standard of care applicable to the defendant physician. ${ }^{208}$ Although the waiver provision does not clearly state to which subsection it applies, the Superior Court has already determined that subsection (a) cannot be waived. ${ }^{209}$ This discretionary bypass is limited as the trial court possesses no discretionary waiver of subsection (b) when the expert is testifying to a standard of care. ${ }^{210}$ Thus, every expert testifying to a standard of care must always satisfy subsection (b). ${ }^{211}$

Subsections (d) and (e) provide a waiver for the trial judge regarding the requirements set forth in subsection (c) for an expert testifying to a standard of care. ${ }^{212}$ Subsection (d) provides a waiver addressing the situation of the "wandering physician," which results when a physician's treatment falls outside the scope of his specialty. ${ }^{213}$ This subsection permits the testimony of an expert experienced in the standard of care of the relevant treatment at issue regardless of whether the defendant physician possessed similar qualifications. $^{214}$ Thus, a physician treating outside the scope of his experience is subject to the standard of care of a physician trained in that specialty. Accordingly, this waiver provision prevents Section 512 from precluding an expert who might have the most relevant knowledge and experience from testifying.

Subsection (e) provides a waiver of the same subspecialty and board certification requirement. ${ }^{215}$ Although a trial court's discretion is restricted to experts who satisfy the requirements established within the waiver provision, ${ }^{216}$ the practical effect of these requirements is limited. Since an expert testifying to a standard of care must always satisfy subsection (b), ${ }^{217}$

207. See $\S 1303.512(\mathrm{~b}),(\mathrm{e})$.

208. Id. $\S 1303.512$ (b).

209. Wexler v. Hecht, 847 A.2d 95, 103 (Pa. Super. Ct. 2004) (regarding subsection (a), the Pennsylvania Superior Court has opined that it simply restates the "baseline" common law requirements for admissibility of an medical expert's testimony, and thus may not be waived).

210. See $\$ 1303.512$ (b) (asserting that "the court may waive the requirements of this subsection for an expert on a matter other than the standard of care") (emphasis added).

211. See id. $\S 1303.512(\mathrm{e})$.

212. Id. § 1303.512(d), (e)

213. See id. $\$ 1303.512(\mathrm{~d})$.

214. See id.

215. Id. $\S 1303.512(\mathrm{e})$

216. See id. $\$ 1303.512(\mathrm{e})$.

217. Id. $\S 1303.512(\mathrm{~b})(2)$. 
any expert considered under this waiver provision must already satisfy subsection (b)(2), which requires an expert to have active clinical or teaching experience in the prior five years. ${ }^{218}$ Subsection (e) specifies a similar requirement that an expert must have experience resulting from active involvement in or full-time teaching of medicine. ${ }^{219}$ Although varying slightly in text, the requirements likely operate with same practical effect. Thus, most experts qualified under subsection (b) will satisfy these requirements for waiver. The practical result of this analysis is that a trial court will possess relatively unlimited discretion to bypass the board certification and same subspecialty requirements.

The strategic limitation of the trial court's discretion evinces a legislative intent to regulate strictly the qualifications of experts testifying to a standard of care, with less concern for experts testifying to other medical issues. However, the legislature made clear through MCARE and Section 512 its intent to apply a more restrictive standard to medical experts testifying in general. ${ }^{220}$ As a result, trial courts should be wary of exercising their discretion when such discretion will permit an expert to subvert the restrictions of Section 512 generally, and trial courts should exercise extreme caution when permitting an expert testifying to a standard of care to bypass the statutory requirements. Trial courts in Pennsylvania have generally adhered to a principle of caution regarding discretionary waivers, precluding experts that fail to satisfy Section 512 requirements except in circumstances where injustice or unfairness might result. ${ }^{221}$

\section{CONCLUSion}

The question that remains is whether Section 512, as interpreted above, will accomplish the legislature's goal of limiting the admissibility of expert testimony in medical malpractice actions, and whether the statute will achieve

218. Id.

219. Id. § $1303.512(\mathrm{e})$

220. See Gartland v. Rosenthal, 850 A.2d 671, 675 (Pa. Super. Ct. 2004).

221. See Herbert v. Parkview Hosp., 854 A.2d 1285, 1294 (Pa. Super. Ct. 2004) (appellate court approved trial court's discretionary waiver as wise because both the expert and the defendant physician had specialized knowledge of the treatment at issue); Amato v. Ctr. Med. \& Surgical Assocs., No. 2002-357, 2004 WL 1987427, at *5 (Centre County Ct. Com. Pl. Aug. 10, 2004) (declining to use discretion when the medical expert retired from clinical practice 15 years prior to testimony); Weiner v. Fisher, $67 \mathrm{~Pa}$. D. \& C.4th 1, 16-17 (Phila. County Ct. Com. Pl. 2004) (declining to apply a discretionary waiver under subsection (e) because, although the expert instructed students, the focus of his instruction did not relate to the treatment at issue). 
its ultimate objective of stabilizing malpractice insurance costs. Currently, no empirical data exists to show that medical malpractice rates have remained affordable or decreased as a result of the implementation of Section 512. Furthermore, isolating Section 512 to analyze its effectiveness separate from other changes implemented in conjunction within MCARE is likely impossible. However, it is apparent under Section 512 that trial courts are rejecting expert testimony previously admissible under the more lenient common law standard, hence the litigation initiated by plaintiffs challenging the statute's constitutionality, as well as the motions in limine and summary judgments in favor of defendant physicians. This more aggressive scrutiny by the trial court of the qualifications of medical experts coincides with the Pennsylvania legislature's goal of restricting the admissibility of testimony to those experts most qualified to testify on medical matters. Although the scale of rejection by trial courts of unqualified experts is not clear, any rejection is proof that the legislature's goal of limiting the admissibility of expert testimony is currently succeeding.

Although resolution of the general issues of Section 512 by Pennsylvania courts to date has resulted in an appreciable restriction of medical expert testimony, much of the statute remains untested. Future litigation will scrutinize closely the precise statutory language and, as a result, the continued success of the statute hinges upon how Pennsylvania courts interpret the key terms of the statute. An expansive interpretation of the terms or a liberal use of discretion to evade the restrictions on expert testimony could undermine the statute's current success and diminish the critical qualification aspects of the statute. As this note makes clear, adherence to the unambiguous meaning of these statutory terms, as mandated by Pennsylvania law, will ensure that the statute will continue to operate to restrict testimony from unqualified experts, thus satisfying this important intermediate goal of the legislature. Ultimately, restricting testimony to only the most qualified experts permits a trial court to ensure that legitimate and qualified malpractice claims are heard while frivolous claims are filtered out. Such equilibrium will permit stabilization in the medical malpractice arena, the ultimate goal of Section 512. 